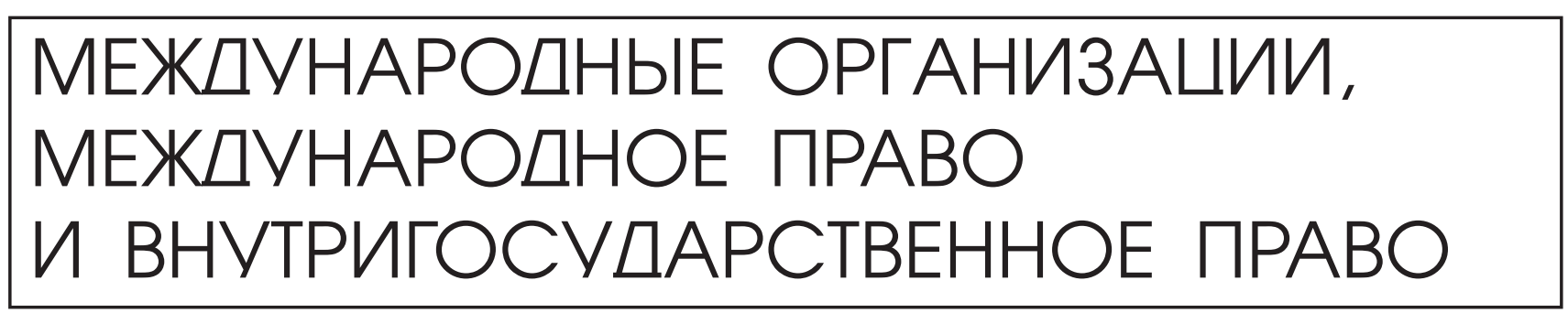

Костенко Н.И.

\title{
ПРОБЛЕМЫ ИМПЛЕМЕНТАЦИИ В МЕЖДУНАРОДНОМ УГОЛОВНОМ ПРАВЕ
}

\begin{abstract}
Аннотация. В статье рассматриваются способы имплементации международно-правовых норм. Дается анализ доктринальных точек зрения по указанной проблеме. Анализируются пробел о трансформации международных договоров, регулирующие отдельные преступления международного характера, которые не включены в уголовное законодательство государств. В тоже время рассматриваются основные точки зрения: дуалистическая и две монополистических, по проблемам соотношения международного и национального законодательства по борьбе с преступностью. Дается принципиальная оиенка юрисдикиии международных трибуна-лов по бывщей Югославии, Руанде и Международного уголовного суда по борьбе с международной преступностью. Анализируется действия международных договоров во времени, в пространстве в условиях глобализаиии по правовому регулированию борьбе с международной преступностью. Методологическую основу данной работы составляет диалектический метод познания с применением принципов развития, иелостности и системности. В работе применялись общенаучные и специальные юридические методы: сравнительный, системно-структурный, теоретико-методологический и др. В работе получили дальнейтее развитие теоретические основы борьбы с преступлениями международного характера (конвенциионными преступлениями). До настоящего времени в российской науке международного уголовного права недостаточно предпринимались исследования по указанной проблеме. Автор предлагает составы преступлений международного характера (конвениионные преступления) классифицировать на 5 (пять) групп, которые в свою очередь составят особенную часть международного уголовного права. Перечень групп и составы преступлений могут быть расширены, трансформированы и инкорпорированы в национальные уголовные кодексы.
\end{abstract} Ключевые слова: договоры, имплементация, трансформация, ратификация, инкорпорация, юрисдикиия, делимитация, экономическая зона, континентальный шельф, коммерческий подкуп

Abstract: The article concerns the means of implementation of international legal norms. The author provides analysis of the doctrinal points of view on this issue, analyzing the gap in law regarding transformation of international treaties regulating specific international crimes, which are not included into the criminal law of the states. At the same time, the author analyzes two leading points of view: dualistic and two monopolistic ones regarding correlation of international and national law in the sphere of fighting crime. The author provides a principal evaluation of the jurisdiction of the International Tribunals for Former Yugoslavia and Rwanda and the International Criminal Court. The author analyzes temporal and territorial application of international treaties on fighting international crime within the framework of globalization. The methodological basis for this work is formed by the dialectic cognition method with the application of principles of development, integrity and systemic character. The article applied general and special legal methods: comparative, systemic structural and theoretical methodological. The article provides further development of the theoretical bases for fighting international crimes (conventional crimes). Till currently there were no sufficient attempts to study this issue in the Russian science of international criminal law. The author offers to divide international crimes (conventional crimes) into five groups, which shall form special part of the international criminal law. The list of groups and elements of crimes may be widened, transformed and incorporated into the national criminal codes.

Keywords: treaties, implementation, transformation, ratification, incorporation, jurisdiction, delimitation, economic zone, continental shelf, commercial bribery. 
оглашения, договоры являются необходимыми институтами человеческого общения. Без его было бы невозможно. При их помощи согласуются совместные действия, разрешаются противоречия ${ }^{1}$. Без них не могли обойтись ни племена, ни государства. Поэтому не случайно договоры между государствами заключаются задолго до возникновения идеи о том, что межгосударственные отношения также должны регулироваться правом. Чем более важные вопросы решаются договором, тем сложнее его достижение и тем важнее его значение ${ }^{2}$. В соответствии со ст.26 Венской Конвенции о праве международных договоров, каждый действующий договор обязателен для его участников и должен ими добросовестно выполняться ${ }^{3}$. Применение международных договоров участниками договора, является целенаправленной деятельностью субъектов, призванные обеспечить осуществление норм международного права.

В литературе, а в значительной мере и в практике, для обозначения осуществления международного права широко используется термин имплементация (лат.-impletum, англ. - implementation).

Имплементация (международного права) implementation «осуществление», «выполнение») - фактическая реализация международных обязательств на внутригосударственном уровне, а также конкретный способ включения международно-правовых норм в национальную правовую систему. Термин используется в широком и узком смысле. В первом случае он означает все меры по реализации норм международного права, во втором - их осуществление во внутригосударственной сфере. В Федеральном законе о международных договорах Российской Федерации в ст. 31

\footnotetext{
${ }^{1}$ См.: Лукашук И.И. Искусство деловых переговоров. М. 2001 .

${ }^{2}$ См.: Лукашук И.И. Современное право международных договоров. В 2 т. Том І. Заключение международных договоров. М. Волтерс Клувер, 2004. С. V.

${ }^{3}$ См.: Международное публичное право. Сборник документов: в 2 ч. ч.I. М. 2006. С.320-339.
}

говориться о выполнении международных договоров Российской Федерацией ${ }^{4}$.

Главное требование имплементации (выполнение) - строгое следование целям и содержанию международного установления.

Способами имплементации являются:

- трансформация,

- инкорпорация

В отечественной международно-правовой доктрине сформировались теории приведения в действие норм международного права в рамках внутригосударственного правопорядка: теория «трансформации» и теория «имплементации», которые и по содержанию и по форме отличаются друг от друга как с точки зрения определения существа этого процесса, так и с точки зрения характеристики основных способов его существования.

В. М. Аверков считает, что используемая в науке терминология «трансформация» произошло от позднелатинского «transformation» , что означает «превращение». Превращение чего-нибудь во что-нибудь, преобразование. Если следовать такому пониманию термина, то нормы международного договора посредством транснациональных норм должны превратиться в нормы иного порядка, то есть в нормы национального законодательства. И как следствие этого, международный договор должен потерять свою «международность» и стать включенным в национальную правовую систему, а также стать источником национального законодательства

В то же время Е.Т. Усенко считал, что основным направлением теории трансформации заключается в том, что осуществление норм международного права во внутреннем праве государства возможно только в случае придания таким международно-правовым нормам силы национального права посредством издания внутригосударственного правового акта ${ }^{5}$.

Так же, Е.T. Усенко считал, что виды трансформации в целом можно подразделить

\footnotetext{
${ }^{4}$ См.: Там же С.379-393.

${ }^{5}$ См.: Усенко E.T. Соотношение и взаимодействие международного и национального права и Российская Конституция // Московский журнал международного права. 1995. № 2. С. 16
} 
на два вида: генеральную и специальную. Он отмечает, что генеральная трансформация заключается в установлении государством в своём внутреннем праве общей нормы, придающей международно-правовым нормам силу внутригосударственного действия. Специальная трансформация заключается в придании государством конкретным нормам международного права силу внутригосударственного действия путем их воспроизведения в законе текстуально либо в виде положений, адаптированных к национальному праву, или путем законодательного выражения согласия на их применение иным способом ${ }^{6}$.

C.В. Черниченко считает, что трансформацию, с точки зрения формы необходимо различать на официальную и неофициальную, а с точки зрения способа осуществления трансформацию следует подразделять на автоматическую и неавтоматическую. Так же он полагает, что трансформация происходит во всех случаях, когда внутригосударственное право приводиться в соответствии с международным, даже и тогда, когда формулировки того или иного международного договора могут породить иллюзию о непосредственном применении его положений для регулирования внутригосударственных отношений ${ }^{7}$.

А.С. Гавердовский в своей работе «Имплементация норм международного права», предлагает рассматривать имплементацию норм международного права как «целенаправленную организационно-правовую деятельность государств, предпринимаемую индивидуально, коллективно или в рамках международных организаций в целях своевременной, всесторонней и полной реализации принятых ими в соответствии с международным правом обязательств ${ }^{8}$.

Автор считает, что трансформационная норма, выражается в согласовании внутригосударственного и международным правом.

\footnotetext{
${ }^{6}$ См.: Усенко Е.T. Там же. С. 17.

${ }^{7}$ См.: Черниченко C.B. Теория международного права. В 2 томах. Том. 1. Современные теоретические проблемы. М., 1999. C. $150-152$.

${ }^{8}$ См.: Гавердовский А. С. Имплементация норм международного права. Киев. 1980. С. 62.
}

При трансформации происходит определенная переработка норм соответствующего международного договора при перенесении их в национальное законодательство (обычно это происходит ввиду необходимости учёта национальных правовых традиций и стандартов юридической техники). В случае общей, частной или конкретной отсылки международно-правовые нормы непосредственно не включаются в текст закона, в последнем содержится лишь упоминание о них.

Наличие трансформационной нормы не означает, что трансформация тем самым уже осуществлена.

В ряде государств ратифицированные международные договоры автоматически становятся частью национального законодательства. Так, в соответствии с Конституцией РФ (ч. 4 ст. 15) в Российской Федерации общепризнанные принципы и нормы международного права и международные договоры Российской Федерации являются составной частью ее правовой системы. Если международным договором Российской Федерации установлены иные правила, чем предусмотренные законом, то применяются правила международного договора.

Д.Б. Левин полагает, что способы согласования внутригосударственного и международного права различны и зависят от права конкретного государства. Государства могут договориться об использовании определенных способов согласования. Но сущность этого процесса, считает Д.Б. Левин, всегда одинакова: приведение государством своего внутреннего права в соответствие с международным с целью обеспечить выполнение предписаний, дозволений и запретов, установленных последним. Наименование указанного процесса в юридической литературе вызывает значительные разногласия. Пожалуй, наиболее распространённым термином для его обозначения является «трансформация», хотя иногда его употребляют в качестве наименования лишь одного из способов согласования международного и внутригосударственного права9.

\footnotetext{
${ }^{9}$ См.: Левин Д.Б. Проблемы соотношения международного и внутригосударственного права //Сов. государство и право. 1964. № 7. С. 91-92.
} 
В то же время Д.Б. Левин считал, что термин «трансформация» охватывает все способы приведения в действие, внутри государства, всех без исключения международных принципов и международных договоров ${ }^{10}$.

C.В. Черниченко полагает, что термин «трансформация» является условным. Отдельные авторы относят к трансформации все способы и формы осуществления международного права посредством права внутригосударственного, в том числе прямую рецепцию международной нормы во внутреннем законе либо отсылку внутреннего закона к международной норме ${ }^{11}$.

Мюллерсон Р.А. считает, что нормы ратифицированного договора могут считаться трансформированными во внутреннее законодательство лишь в случае, если имеется указание на то, что международный договор является частью внутреннего права страны $^{12}$. В то же время в категоричной форме А.Н. Талалаев отмечает, что ратифицированный договор приобретает силу национального закона, и о его «трансформации» в правовую систему государства не может быть и речи ${ }^{13}$.

Обратим внимание на соответствие международных договоров Конституции Российской Федерации. В соответствии со ст. 34 Федерального закона «О международных договорах Российской Федерации» от 15 июля 1995 г. ${ }^{14}$ Конституционный суд РФ разрешает дела о «не вступивших в силу международных договоров Российской Федерации». К категории договоров «не вступивших в силу» относятся договоры, находящиеся на различных стадиях заключения - начиная от установления аутентичности текста и кончая согласием на его обязательность, включая ратификацию. Двусторонний договор мог

\footnotetext{
${ }^{10}$ См.: Левин Д.Б. Указ. соч. С. 250-253.

${ }^{11}$ См.: Черниченко С.В. Личность и международное право. M., 1974. C. 50-52.

${ }^{12}$ См.: Мюллерсон Р.А. Соотношение международного и национального права. М. 1982. С. 73-75.

${ }^{13}$ См.: Талалаев А.Н. Юридическая природа международного договора. М. 1963. С. 251-253.

${ }^{14}$ См.: С3 РФ. 1995. № 29. Ст. 2757.
}

быть ратифицирован РФ и другой стороной, но обмен ратификационными грамотами еще не произошёл, по этой причине договор в силу ещё не вступил. Ратифицированный многосторонний договор может не вступить в силу в течение многих лет. Возникает вопрос: вправе ли Конституционный суд РФ рассматривать дело о конституционности договора, если Российская Федерация дала своё согласие на его обязательность, но он еще не вступил в силу?

Если обратиться к международному праву, то окажется, что односторонний отказ от согласия на обязательность договора недопустим. Он может иметь место при условиях, установленных для этого правом договоров. Противоречие договора Конституции не является для этого основанием. На этот счет Венские конвенции закрепили норму о недопустимости ссылок на положение своего внутреннего права для определения невыполнения договора (ст. 27). Они прямо запрещают государству ссылаться на то обстоятельство, что его согласие на обязательность договора было выражено в нарушение положения его внутреннего права, касающегося компетенции заключать договоры, как на основании недействительности его согласия. Из этого правила делается лишь одно исключение, когда нарушение норм о компетенции заключать договоры было явным и касалось нормы права особо важного значения (п.1 ст. 46 Конвенции).

Международное право и Федеральный закон «О международных договорах Российской Федерации» (ст. 23) предусматривает возможность временного применения договора до его вступления в силу. Признание договора не конституционным означает, что договор далее не может применяться даже временно.

Конституционный суд РФ рассматривает конституционность не только договора в целом, но и «отдельных его положений». В праве международных договоров существует правило единства, неделимости текста договора, которое не допускает частичного принятия или прекращения договора без согласия других участников. Постановление суда о не конституционности даже отдельно- 
го положения договора будет означать отказ от него в целом.

Рост роли международного права и значения его соблюдения всеми органами государства придает особую важность судебному контролю за соответствием внутригосударственного права и практике его применения обязательствам государства по международному праву.

Порой Конституционный суд РФ может играть существенную роль в решении спорных вопросов относительно правомерности заключения договора по внутреннему праву.

Существенную роль играют судебные решения в осуществлении договоров. Показательно в этом отношении Постановления Пленума Верховного Суда РФ от 10 октября 2003 г. «О применении судами общей юрисдикции общепризнанных принципов и норм международного права и международных договоров Российской Федерации» ${ }^{15}$.

В настоящее время договорная практика Российской Федерации уделяет значительное внимание развитию международных связей в борьбе с преступностью. Что на сегодняшний день является очень актуальным и востребованным.

И.И. Лукашук считал, что сам процесс воплощения в действия международных договоров, необходимо рассматривать как двуединство правотворческой и организационно-исполнительной деятельности государств. И на этот счёт, для его обозначения используется термин «имплементация» ${ }^{16}$.

Что же касается второго способа имплементации - инкорпорация, то при инкорпорации международно-правовые нормы без каких-либо изменений дословно воспроизводятся в законах имплементирующего государства.

Инкорпорация - формальное «включение» норм международного договора во внутреннее право государства посредством «включения» самого договора в его законо-

\footnotetext{
${ }^{15}$ См.: Бюллетень Верховного суда РФ № 42003 г.

${ }^{16}$ См.: Лукашук И.И. Функционирование международного права. М., 1992. С. 36.
}

дательство. Следует заметить, что ни сам международный договор, ни нормы, которые он содержит, не включаются соответственно ни в законодательство, ни в право данного государства. Международный договор продолжает оставаться международным договором, обязывающим это государство, а нормы, которые он содержит, остаются нормами международного права, распространяющими на конкретное государство своё действие. При такой ситуации принимается новый закон или подзаконный акт полностью внешне идентичный международному договору: повторяющий его название, структуру, формулировки и т.д.

Таким образом, при имплементации путем отсылки применение национальной правовой нормы становится невозможным без непосредственного обращения к первоисточнику - тексту соответствующего международного договора.

Что же касается проблемы имплементации международного уголовного права и национальной уголовной юстиции, на сегодняшний день, то она имеют важное значение с точки зрения борьбы с международной и транснациональной организованной преступностью.

В законодательстве России на сегодняшний день усматривается пробел в регламентации порядка включения в Уголовный кодекс Российской Федерации ратифицированных и вступивших в силу Конвенций Организации объединенных Наций и Совета Европы в борьбе с международной и транснациональной организованной преступностью, коррупцией и терроризмом и т.д. Конституция Российской Федерации международным договорам придает высшую силу. Как уже упоминалось, в соответствии с ч. 4 ст. 15 Конституции РФ, общепризнанные принципы и нормы международного права и международные договоры являются составной частью её правовой системы. При этом, если международным договором Российской Федерации установленные иные правила, чем предусмотренные законом, то применяются правила международного договора. В отношении международного уголовного права данное положение применимо, в пер- 
вую очередь, к договорам об ответственности лиц, обладающих иммунитетом, выдаче лиц, совершивших преступления, другому государству. Уголовно-правовые санкции за отдельные виды преступлений международным правом не предусмотрены, и ответственность за конкретные преступления наступает по законодательству или по решению специализированных международных судов (Международного уголовного суда) в каждом конкретном случае.

В последнее время Федеральное Собрание Российской Федерации в лице Государственной Думы ратифицировало целый ряд международных конвенций, таких как, Конвенция Организации Объединенных Наций против транснациональной организованной преступности, принята Генеральной Ассамблеи от 15 ноября 2000 г. $^{17}$, Шанхайская конвенция о борьбе с терроризмом, сепаратизмом и экстремизмом от 15 июня $2001 \Gamma^{18}{ }^{18}$, Конвенция Организации Объединенных Наций против коррупции, принята Генеральной Ассамблеи от 31 октября 2003 г. ${ }^{19}$ и т.Д., что составили правовую систему Российской Федерации.

Совокупность специфических особенностей российского уголовного законодательства, состоит в том, что органы предварительного следствия и суды при квалификации преступлений и назначении наказаний не смогут применить правовые нормы конкретных Конвенций. На этот счет необходимо полагать, что конвенционные правовые нормы должны быть трансформированы (имплементированы) в отдельные статьи Уголовного кодекса Российской Федерации. На этот счет И.П. Блищенко считал, что в этих условиях проявляется две тенденции, которые необходимо учитывать при ответе на вопрос о природе соотношения международного и

\footnotetext{
${ }^{17}$ См.: Международное публичное право. Сборник документов. Ч.ІІ. М., 2006. С. 1039-1961.

${ }^{18}$ См.: Терроризм. Правовые аспекты противодействия: нормативные и международные правовые акты с комментариями, научные статьи/под ред. И. Л. Трунова и Ю.С. Горбунова. Изд.и 2-е, перераб. и доп. М. 2007. С. 648-655.

${ }^{19}$ См.: Документ Генеральной Ассамблеи ООН 58 сессия А/ $\mathrm{RES} / 58 / 4$.
}

внутригосударственного уголовного права. Первая тенденция - это тесная взаимосвязь правовых норм, регулирующих одну и ту же область отношений, их взаимное влияние и проникновение, вторая тенденция - решение традиционных вопросов внутригосударственного права путем заключения международного, межгосударственного соглашения ${ }^{20}$.

По проблемам соотношения международного и национального права наука выработала три основные точки зрения: дуалистическая и две монистических. Основатели дуалистической концепции были Г. Трипель и Д. Анцилотти, которые рассматривали международное и национальное право, как юридически равноправных правовых систем и источники которых не могут конкурировать друг с другом. По мнению Д. А. Левина, это два круга, которые тесно соприкасаются, но никогда не пересекаются» ${ }^{21}$.

Сторонники первой монистической теории, напротив утверждают о приоритете внутригосударственного права над международным правом (А. Цорн, А. Лассон). Сторонники второй монистической теории (Г. Кельзен, Дж. Кунц) обосновали идею свою точку зрения, что международное право является приматом над внутригосударственным правом ${ }^{22}$.

Я. Броунли в категоричной форме считал, что монистические теории не соответствуют правовым реальностям существования суверенных государств и международного права как юридического феномена. Вследствие этого в науке возобладал дуалистический подход в понимании соотношения внутригосударственного и международного права ${ }^{23}$. В свою же очередь Д. Анцилоттин считает, что суть дуалистического подхода заключается в том, международное и внутригосударственное право рассматриваются не просто как

\footnotetext{
${ }^{20}$ См.: Международное у головное право. Учебн. Пособие/ Под ред. В.Н. Кудрявцева М. 1999. С. 36.

${ }^{21}$ См.: Левин Д.А. Актуальные проблемы теории международного права. М., 1974. С. 195-196.

${ }^{22}$ См.: Kelsen H. Principler of international Law. N., 1967. P. 177.

${ }^{23}$ См.: Броунли Я. Международное право. Т.1. М., 1977. C. 65-67.
} 
различные отрасли права, а они представляют собой отдельные правопорядки ${ }^{24}$.

Д. Б. Левин, отмечал, что международное и внутригосударственное право, являются двумя различными правовыми системами по всем своим основным элементам: по объекту права, по субъектам права, по структуре правоотношений и по источникам права. Лишь частично совпадают объекты права. Именно это и вызывает к жизни саму проблему соотношения международного и внутригосударственного права. Он также считал, что это практически одна проблема, поскольку имеется в виду юридическое соотношение обеих систем, в первую очередь сводиться к способам выполнения норм международного права внутри данного государства ${ }^{25}$.

С. В. Черниченко считает, что процесс согласования внутригосударственного и международного права, направленный на обеспечение выполнения положений международного права внутригосударственным правом, неизбежен и обеспечен наличием объективных границ между внутригосударственным и международным правом. Он начинается до стадии осуществления соответствующих положений внутригосударственного права. Он может начаться сразу же или вскоре после распространения на государство действия конкретных международно-правовых норм и даже до распространения на него действия таких норм ${ }^{26}$.

Заключительный акт Совещания по безопасности и сотрудничеству в Европе от 1 августа 1975 г. подчеркнул, что государства должны устанавливать законы в соответствии со своими юридическими обязательствами по международному праву, учитывать и выполнять должным образом положении Заключительного акта.

Такой подход очень важный, когда речь идет о международном уголовном праве, ко-

\footnotetext{
${ }^{24}$ См.: Анциилоттин Д. Курс международного права. Т.1. М., 1961. C. 65-67.

${ }^{25}$ См.: Левин Д.Б. Указ. соч. С. 244-246.

${ }^{26}$ См.: Черниченко С. В. Теория международного права. В 2-х томах. Том. 1: Современные теоретические проблемы. M. 199. C. 148.
}

торое не только служит важным орудием в борьбе с международными преступлениями и преступлениями международного характера, но и является важным элементом укрепления системы международной безопасности ${ }^{27}$.

Соотношение международного уголовного и национально-уголовного права, то есть имплементация международного уголовного права, выраженная в конкретных международных договорах находит свое выражение в национальном уголовном праве, особенно когда речь идет о санкциях за международные преступления и преступления международного характера.

На основании изложенного можно сделать вывод, что становление и развитие международного уголовного права, с одной стороны, прямо испытывало на себе влияние национального, а с другой - международное уголовное право стало оказывать влияние на территории государства на внутреннее уголовное право.

Рассматривая вопрос имплементации норм международного уголовного права, не представляется возможным обойти вопрос о применении международных норм во времени и пространстве. На мой взгляд, одна из самых важных проблем в науке международного уголовного права. Действие международного уголовного права во времени определяется принципами Нюрберга на современное международное уголовное право. Необходимо заметить, что проблема наказания главных немецких военных преступников, осужденных Нюрнбергским трибуналом, и в настоящее время сохраняет свою актуальность.

Действие международного уголовного права во времени - это принцип ratione temporis.

Необходимо обратить внимание, что в соответствии с указанным принципом совершаемые преступления должны определять международно-правовой нормой,

\footnotetext{
${ }^{27}$ См.: Международное уголовное право. Учебное пособие/ Под общей ред. В.Н. Кудрявцева. 2-е изд. пераб. и доп. - М.: Наука. 1999. С.38
} 
которая существовала на момент совершения преступления.

Основными правовыми источниками международного уголовного права являются: принципы международного права, международный договор, конвенции международных организаций, обычные нормы. Действие указанных источников международного уголовного права во времени зависит от его правовой направленности.

Если брать за основу международный договор, то он действует во времени и пространстве. Он определяет, в какое время, в каком месте предписанное им действие должно осуществляться, и поэтому его действие имеет пространственный и временный характер. Когда в международном договоре не указаны место его действия и время, то это не следует понимать, что такой договор независим от явления, которое происходит в определенное время.

Действие во времени норм международного уголовного права связывается с действием всего договора в целом.

Данному вопросу посвящена содержащаяся в Венской конвенции о праве международных договоров, от 23 мая 1969 г. ${ }^{28}$ первая статья раздела «Общие положения» части «Недействительность, прекращение и приостановление действие договоров» (ст. 42).

В. М. Шуршалов предложил широкое понятие действительности договоров, которое включало эффективность договора, его долговечность, справедливость и правомерность ${ }^{29}$. В тоже время А.Н. Талалаев считал, что понятие действительности шире понятия правомерности. И утверждал, что юридическая полноценность международного договора в плане не только его соответствия международному праву (правомерность), но и наличие в нем сторон, обладающих международной правосубъектностью ${ }^{30}$. Мне кажется, что с таким мнением трудно согласиться, по

\footnotetext{
${ }^{28}$ См.: Действующее международное право.Т1.М. 1996 С. 356.

${ }^{29}$ См.: Шуршалов В.М. Основания действительности международных договоров. М. 1957. С. 7.

${ }^{30}$ См.: Талалаев А.Н. Венская конвенция о праве международных договоров. Комментарий. М. 1997. С. 116.
}

той причине, что обладание правосубъектностью, должно присутствовать наличие соглашение воль, которое должно регулироваться международным правом.

М.А. Капустина считает, что действие международного договора во времени обычно связывается с действием всего договора в целом. Она утверждает, что действие отдельной договорной нормы может существенным образом отличаться от действия договора в целом ${ }^{31}$.

Значительное внимание действительности договоров уделили А.Т. Талалаев и В. М. Шуршалов которые предложили широкое понятие действительности, которое включало правомерность, долговечность, справедливость и эффективность договора ${ }^{32}$.

И.И. Лукашук считал, что недействительность, прекращения или приостановление действия договора не затрагивает обязанность государств или организаций выполнять любое записанное в договоре обязательство, которое имеет силу для них в соответствии с международным правом, независимо от данного договора. Он полагал, что такими обязательствами являются те, которые вытекают из обычных норм международного права, а также из иных договоров. Прекращение действия определенного договора не влияет на обязательства по другим источникам международного права ${ }^{33}$.

Следует заметить, что нормы международного уголовного права, как правило, являются императивными нормами и их обязательность может возникнуть только тогда, когда сам договор вступает в силу.

В Венской Конвенции о праве международных договор от 23 мая 1969 г. предусмотрено, что она вступает в силу после сдачи на хранения 35-й ратификационной грамоты. То есть достаточно 35 участников, сдавших

\footnotetext{
${ }^{31}$ См.: Капустина M.A. Действие норм международных договоров во времени: теоретико-правовой анализ // Правоведение. 1998 . № 2. С. 51-52.

${ }^{32}$ См.: Шуршалов В.М. Основания действительности международных договоров. М., 1957. С. 7.

${ }^{33}$ См.: Современное право международных договоров. Т.ІІ. М.: Волтер Клувер, 2006. С. 89.
} 
ратификационную грамоту. Для каждого отдельного взятого государства. Конвенция вступает в силу на 30 день после её сдачи её на хранения. А.Н. Талалаев считал, что международный договор вообще может не вступать в силу, но это не будет препятствовать действию правовых норм во времени. Почему? Потому, что международно-правовые нормы создаются государствами и международными организациями и соглашения между ними является окончательным для начала действия такой нормы ${ }^{34}$. Необходимо обратить внимание, что действительность международного договора - это особое его качество как источник международного права. Только действительные международные договоры могут быть источниками обязательных для государств международно-правовых норм. Юридическая действительность, в том числе международных договоров, не может оцениваться с точки зрения политических или экономических критериев.

Действительность международных договоров может иметь юридические основания, определяемые международным правом. С такой точки зрения можно считать, что она определяется как международно-правовая правомерность договора, его полноценность, в силу которой он является обязательным для выполнения его участниками и для уважения всеми другими государствами ${ }^{35}$.

Действительность включает в себя правомерность, но не ограничивается ею. Понятие действительности шире понятия правомерности: это юридическая полноценность международного договора в плане не только его соответствия международному праву, но и наличие в нем сторон, обладающих международной правосубъектностью, соглашение их воль и т.д.

Только действительные международные договоры могут порождать правомерные последствия для договаривающихся сторон и только по таким договорам стороны могут

\footnotetext{
${ }^{34}$ См.: Талалаев А.Н. Венская конвенция о праве международных договоров. Комментарий. М., 1997. С. 116.

${ }^{35}$ См.: Landers D. Worterbuch der Deutschen Spraehe. Bd.I. Leipzig, 1848. S.639.
}

приобретать законные, а не мнимые права и обязанности, на достижение которых была направлена воля участников договора. На мой взгляд - это главное в содержании понятия действительности.

Д. Ландерс считает, что в Венской конвенции о праве международных договоров, от 23 мая 1969 г. в ст. 28 сформулирован принцип отсутствия у международных договоров обратной силы. По некоторым данным, лишь девять с небольшим процентов договоров имеют обратную силу, из них две трети сроком не более одного года, а половина - до трех месяцев, что позволяет считать ретроактивность (обратную силу) договоров исключением, а неретроактивность - правило ${ }^{36}$. На этот счет следует полагать, что положения международного договора обязательны для его участника только в отношении действий или фактов, которые имели место после вступления договора в силу для указанного участника, или в отношении ситуаций, которые продолжали существовать и не прекратились после вступления договора в силу.

Указанная статья договора не запрещает участникам договора по взаимному согласию распространить действия договора на события и факты, которые имели место до вступления его в силу, или на ситуации, которые перестали существовать до такой даты. Взаимное согласие об этом может быть зафиксировано в самом международном и в дополнительном протоколе к нему.

Н. И. Марышева отмечает, что на практике, в некоторых договорах о правой помощи хотя и допускается распространение их действия на правоотношения, возникшие после вступления договора в силу, но судебная практика идет по линии исполнения судебных решений по правоотношениям, возникшим и до вступления договора в силу ${ }^{37}$.

Принцип неретроактивности не нарушается применением международного договора к вопросам, которые возникли до вступления

\footnotetext{
${ }^{36}$ Cм.: Tavernier P. Recherhes sur Papplication dans le temps des actes et de regles en droit international public. P. 1970. P.39-45.

${ }^{37}$ См.: Марышева Н.И. Рассмотрение судами гражданских дел с участием иностранцев. М.1970. С. 96-98.
} 
договора в силу, если эти вопросы продолжают существовать. Например, Европейская комиссия по правам человека не считала себя вправе рассматривать обоснованность законодательных, административных или судебных актов, принятых до вступления в силу Европейской конвенции о защите прав человека и основных свобод 1950 г,, она применила на себя юрисдикцию в тех случаях, когда разбирательство имело место недавно или эти акты применялись повторно после вступления Конвенции в силу ${ }^{38}$.

Статья 54 Венской конвенций о праве международных договоров предусматривает случаи прекращения международных договоров по соглашению их участников. В пункте «а» указанной статьи это соглашение содержится в самом договоре, в пункте «b»-вне его. Но обоих случаях прекращение международного договора основано на соглашении его участников.

Международные договоры могут быть определенно - срочными, неопределенно срочными и бессрочными. Определённым сроком действия договора считается отрезок времени, точно установленный в самом договоре. Определённый срок может быть, безусловно-определённым и условно-определённым.

Безусловно - определённый срок формулируется в договорах следующим образом: «Настоящий договор будет действовать в течение трех лет, считая со дня вступления в силу». Или же в договоре устанавливается, что договор будет действовать до 31 декабря такого такого-то года.

Условно-определенный срок - это тоже определённый срок, но с дополнительным условием о том, что после его истечения будет действовать другой определённый срок, если одна их сторон не предупредит о своём отказе от него в срок, предусмотренный в договоре. В обоих случаях наступление определённой даты автоматически прекращает действия договора. Необходимо отметить, что при решении этого вопроса нужно иметь в виду, что международный договор может быть про-

${ }^{38}$ См.:Yearbook of the European Convention of Human Rights. 1958-1959. P/ 230-235. лонгирован или же возобновлён специальным соглашением сторон. Тогда его действие не прекращается и договор восстанавливается.

Иногда возникает вопрос о влиянии прекращения договора между двумя сторонами, который прекратил или приостановил действие на ранее заключенный между ними договор. В таком случае решающее значение имеют формулировки последующего договора. Если в нем используется, например, такое слово, как «заменить», то это будет означать, что прежний договор полностью отменен.

Последствия недействительности договора, противоречащего императивной норме, представляет собой прогрессивное развитие международного права.

Из этого вытекает, что в случае противоречия договора существующей императивной норме он является недействительным с самого начала, т.е. ничтожным (ст. 53 Конвенции), участники устанавливают последствия любого действия, совершенного на основании положения, противоречащего императивной норме. На основании изложенного следует, что, несмотря на недействительность договора с самого начала, совершенные в соответствии с ним действия сохраняют свою силу, если они совершены на основании положений, не противоречащих императивной норме. В тоже время, участники обязаны привести свои взаимоотношения в соответствии с императивной нормой.

Таким образом, можно подвести итог, что прекращение действия международного договора может быть в нескольких случаях. Во-первых, когда действие международного договора, или его части отменено по причине несоответствия принципам международного, тем самым противоречат императивной норме. Во-вторых, когда бессрочный договор утрачивает силу вследствие его замены вновь заключенным договором. В-третьих, когда международный договор заключен на определённый срок, и по истечении срока он теряет юридические обязанности для сторон, его подписавшего. И в-четвертых, когда государство-участник договора выходит из договора. На основании изложенного можно констатировать тот факт, что нормы 
международного уголовного права трансформированы из международного права и в то же время подчиняются правилам и прицепам международного права.

Некоторые договоры не имеют четко определённой территориальной сферы действия. При всех условиях они должны иметь ту же сферу действия, что и суверенитет участников.

Большинство договоров имеет четкую территориальную сферу действия. Пределы государственной территории определяются международным правом. Она включает сухопутную территорию, внутренние и территориальные воды, воздушное пространство над ними. В некоторых случаях такие территории специально указываются в международных договорах, например, Парижский договор от 9 февраля 1920 г. «О Шпицбергене» в котором участники договора признали суверенитет Норвегии над архипелагом Шпицберген, включая Медвежий остров, с той целью, чтобы в этих местностях имелся надлежащий режим, способный обеспечить их развитие и мирное использование. Другой договор, договор об Антарктике (Antarctic Treaty) был подписан 1 декабря 1959 г. в Вашингтоне двенадцатью государствами, ученые которых активно участвовали в антарктической деятельности во время Международного геофизического года 1957-1958. Сегодня в число участников Договора входят 45 государств, 27 из которых являются консультативными сторонами. Его главная цель - обеспечить использование Антарктики в интересах всего человечества. «Антарктика используется только в мирных целях» (ст. I). В Договоре утверждается свобода научных исследований и поощряется международное сотрудничество. Среди вопросов, трактуемых Договором об Антарктике особое место занимают территориальные претензии на районы к югу от $60^{\circ}$ ю. ш. Многие договоры, имеют территориальное действие, не указывают его пределы. В качестве примера можно привести договоры о выдаче. Второй пример, в типовом договоре о выдаче от 14 декабря 1990 г. № 45/116 говориться, что Генеральная Ассамблея, принимая во внимание Миланский план действий, принятый седьмым Конгрессом
Организации Объединенных Наций по предупреждению преступности и обращению с правонарушителями и одобренный Генеральной Ассамблеей в ее Резолюции 40/32 от 29 ноября 1985 года, принимая во внимание также Руководящие принципы в области предупреждения преступности и уголовного правосудия в контексте развития и нового международного экономического порядка, принцип которых предусматривает, что Организации Объединенных Наций следует подготовить типовые документы, которые можно было бы использовать в качестве международных и региональных конвенций, а также в качестве ориентиров при осуществлении национальной законодательной политики.

Сфера действия договора определяется участниками. Тем не менее, в качестве общего правила договор касается всей территории государства. В международной практике признается, что договор подлежит применению в отношении всей территории государства, если иное в нем не оговорено ${ }^{39}$.

Что касается Российской Федерации, то территория России определена её Конституцией в соответствии с международным правом, включает территории субъектов Федерации, внутренние воды и территориальное море, воздушное пространство над ним (ч.1 ст. 67. Кроме того «Российская Федерация обладает суверенными правами и осуществляет юрисдикцию на континентальном шельфе и в исключительной экономической зоне Российской Федерации в порядке, определяемом федеральным законом и нормами международного права» (ч.2 ст. 67).

Понимание территории закреплено в договорной практике. В ней определяют территорию государства, в пределах которой оно осуществляет собственно территорию и полную юрисдикцию государства.

К государственной территории Российской Федерации относится: суша, воды, недра и воздушное пространство в пределах государ-

\footnotetext{
${ }^{39}$ CM.: Succession of States in relation to General Multilfteral Treaties of wnich the Secretary-general is Depositary (A/CN4/150) P. 73-74, 138.
} 
ственной границы Российской Федерации. В соответствии с Законом РФ «О государственной границе Российской федерации» от 1 апреля 1993 г. Государственной границей Российской Федерации является граница РФ, закрепленная действующими международными договорами и законодательными актами бывшего СССР.

Территория государства определяется двусторонними договорами. Например, соглашение между Российской Федерацией и ФРГ «О воздушном пространстве от 14. 071993 г. в котором говориться, что Правительство Российской Федерации и Правительство Федеративной Республики Германии, являясь участниками Конвенции о международной гражданской авиации, открытой для подписания в Чикаго 7 декабря 1944г., заключает Соглашение об установлении и осуществлении воздушного сообщения между их территориями и за их пределы.

Следует заметить, что в международной практике, в соответствии с принятыми Конвенциями ООН постоянно отмечается наступление ответственности за международные преступления и преступления международного характера согласно территориальному принципу действия закона в пространстве ${ }^{40}$.

В Уставе Международного трибунала для судебного преследования лиц, ответственных за серьезные нарушения международного гуманитарного права, совершенные на территории бывшей Югославии с 1991 года, учрежденный Советом Безопасности, действующим на основании главы VII Устава Организации Объединенных Наций, принятый 25 мая 1993 г. Резолюцией 827 Совета Безопасности ООН с поправками от 13 мая 1998 (Резолюция 1166), 30 ноября 2000 г. (Резолюция 1329), 17 мая 2002 г. (Резолюция 1411), 14 августа 2002 г. (Резолюция 1431), 19 мая 2003 г. (Резолюция 1481), говориться, что «Территориальная юрисдикция Международного трибунала распространяется на территорию бывшей Социалистической

${ }^{40}$ См.: Иногамова-Хегай Л.В. Международное уголовное право. СПб. Изд. «юридический центр Пресс» 2003. С.85.
Федеративной Республики Югославии, включая ее сухопутную территорию, воздушное пространство и территориальные воды» (ст. 8).

Аналогичные нормы предусмотрены в Уставе Международного уголовного трибунала для судебного преследования лиц, ответственных за геноцид и другие серьезные нарушения международного гуманитарного права, совершенные на территории Руанды, и граждан Руанды, ответственных за геноцид и другие подобные нарушения, совершенные на территории соседних государств, в период с 1 января 1994 года по 31 декабря 1994 года, учрежденного Советом Безопасности, действующим на основании главы VII Устава Организации Объединенных Наций.

В ст. 7 Устава говориться, что территориальная юрисдикция Международного трибунала по Руанде распространяется на территорию Руанды, включая ее сухопутную территорию и воздушное пространство, а также на территорию соседних государств в отношении серьезных нарушений международного гуманитарного права, совершенных гражданами Руанды. Временная юрисдикция Международного трибунала по Руанде распространяется на период, начинающийся 1 января 1994 года и заканчивающийся 31 декабря 1994 года.

В соответствии с ст. 4 Римского статута международного уголовного суда, Суд обладает международной правосубъектностью. Он также обладает такой же правосубъектностью, какая может оказаться необходимой для осуществления его функций и достижения его целей.

Суд может осуществлять свои функции и полномочия, как это предусмотрено в Статуте, на территории любого государства-участника и, по специальному соглашению, на территории любого другого государства.

Суд может осуществлять свою юрисдикцию, если одно или несколько государств являются участниками Статута или признают юрисдикцию Суда.

В качестве примера, более широкого понятия территории, можно привести Мирный договор с Японией подписан в Сан-Франциско 8 сентября 1951 г., где в ст. 2 
говориться: а) Япония, признавая независимость Кореи, отказывается от всех прав, правооснований и претензий на Корею, включая острова Квельпарт, порт Гамильтон и Дагелет; b) Япония отказывается от всех прав, правооснований и претензий на Формозу и Пескадольские острова; с) Япония отказывается от всех прав, правооснований и претензий на Курильские острова и на ту часть острова Сахалин и прилегающих к нему островов, суверенитет над которыми Япония приобрела по Портсмутскому Договору от 5 сентября 1905 г.; d) Япония отказывается от всех прав, правооснований и претензий, связанных с мандатной системой Лиги Наций, и принимает решение Совета Безопасности Организации Объединённых Наций от 2 апреля 1947 г., по которому система опеки распространяется на Тихоокеанские острова, находящиеся ранее мандатом Японии; е) Япония отказывается от всех претензий на какие-либо права, правооснований или интересы в отношении любой части Антарктического района, независимо от того вытекали ли они из деятельности японских граждан или были получены иным образом; t) Япония отказывается от всех прав, правооснований и претензий на острова Спратли и острова Парасельские.

Международным уголовным правом предусмотрена и параллельная юрисдикция.

«Международный трибунал и национальные суды имеют параллельную юрисдикцию в отношении судебного преследования лиц за серьезные нарушения международного гуманитарного права, совершенные на территории бывшей Югославии с 1 января 1991 года» (ст. 9).

«Юрисдикция Международного трибунала имеет приоритет по отношению к юрисдикции национальных судов. На любом этапе судебного разбирательства Международный трибунал может официально просить национальные суды передать производство по делу Международному трибуналу в соответствии с настоящим Уставом и правилами процедуры и доказывания Международного трибунала» (ст. 10).
Международный трибунал по Руанде и национальные суды имеют параллельную юрисдикцию в отношении судебного преследования лиц за серьезные нарушения международного гуманитарного права, совершенные на территории Руанды, и судебного преследования граждан Руанды за подобные нарушения, совершенные на территории соседних государств, в период с 1 января 1994 года по 31 декабря 1994 года.

Юрисдикция Международного трибунала по Руанде имеет приоритет по отношению к юрисдикции национальных судов всех государств. На любом этапе судебного разбирательства Международный трибунал по Руанде может официально просить национальные суды передать ему производство по делу в соответствии с настоящим Уставом и правилами процедуры и доказывания Международного трибунала по Руанде (ст. 8).

В соответствии с ст. 17 Статутом Римского международного уголовного суда, Суд определяет, что дело не может быть принято к производству в тех случаях, когда:

а) данное дело расследуется или в отношении его возбуждено уголовное преследование государством, которое обладает в отношении его юрисдикцией, за исключением случаев, когда это государство не желает или не способно вести расследование или возбудить уголовное преследование должным образом;

b) дело расследовано государством, которое обладает юрисдикцией в отношении него, и это государство решило не возбуждать в отношении лица, которого это касается, уголовного преследования, за исключением случаев, когда это решение стало результатом нежелания или неспособности государства возбудить уголовное преследование должным образом.

В Статуте Международного уголовного суда (ст. 1) говориться, что Суд является постоянным органом, уполномоченным осуществлять юрисдикцию в отношении лиц, ответственных за самые серьёзные преступления, вызывающие озабоченность международного сообщества и дополняет национальные органы уголовной юстиции.

В Российской Федерации территориальный принцип действия уголовного закона 
всегда ограничено определенной территорией. В связи с этим важным принципом действия уголовного закона в пространстве является территориальный принцип (ч.1 ст. 11 Уголовный кодекс Российской Федерации, далее УК РФ). И данный принцип сводится к тому, что лица совершившие преступления на территории Российской Федерации, независимо от того, являются ли они российскими гражданами, иностранными гражданами или лицами без гражданства, несут уголовную ответственность по УК РФ.

К государственной территории Российской Федерации относятся: суша, воды, недра и воздушное пространство в пределах Государственной границы Российской Федерации. В соответствии с Законом РФ «О Государственной границе Российской Федерации» от 1 апреля 1993 г. ${ }^{41}$ Государственная граница Российской Федерации является граница РСФСР, закреплённая действующими международными договорами и законодательными актами бывшего СССР.

В соответствии с ч. 2 ст. 11 УК РФ преступление, совершенное в пределах территориальных вод или воздушного пространства Российской Федерации, признаётся совершенными на территории Российской Федерации. Действие УК РФ распространяется на преступления, совершенные на континентальном шельфе или в исключительной экономической зоне Российской Федерации.

В соответствии с Федеральным законом РФ «О континентальном шельфе Российской Федерации» ${ }^{42}$, континентальный шельф Российской Федерации (далее - континентальный шельф) включает в себя морское дно и недра подводных районов, находящиеся за пределами территориального моря Российской Федерации (далее - территориальное море) на всем протяжении естественного продолжения ее сухопутной

\footnotetext{
${ }^{41}$ См.: Ведомости Съезда народных депутатов Российской Федерации и Верховного Совета Российской Федерации, 1993, № 17, ст. 594; С3 РФ, 1994, № 16, ст. 1861.

${ }^{42}$ См.: СЗ РФ, 1995, № 49, ст. 4694; 1999, №7, ст. 879; 2001, № 33 , ст. 3429 ; 2003, № 17, ст. 1557; № 46, ст. 4444; 2004, № 35 , ст. 3607 ; 2006,№ 45, ст. 4640; 2007,№ 50, ст. 6246; 2008,№ 18 , ст. 1941.
}

территории до внешней границы подводной окраины материка.

Подводной окраиной материка является продолжение континентального массива Российской Федерации, включающего в себя поверхность и недра континентального шельфа, склона и подъема.

Определение континентального шельфа применяется также ко всем островам Российской Федерации (ст. 1). Подводной окраиной материка является продолжение континентального массива РФ, включая в себя поверхность и недра континентального шельфа, склона и подъёма.

Внутренней границей континентального шельфа является внешняя граница территориального моря.

С учетом положений настоящего Федерального закона внешняя граница континентального шельфа находится на расстоянии 200 морских миль от исходных линий, от которых отмеряется ширина территориального моря, при условии, что внешняя граница подводной окраины материка не простирается на расстояние более чем 200 морских миль.

Если подводная окраина материка простирается на расстояние более 200 морских миль от указанных исходных линий, внешняя граница континентального шельфа совпадает с внешней границей подводной окраины материка, определяемой в соответствии с нормами международного права (ст. 1). Данный закон определяет и пространственные пределы внутренней и внешней границ континентального шельфа. Особый правовой режим континентального шельфа в первую очередь связан с необходимостью охраны его природных ресурсов, с необходимостью защиты и сохранения морской среды в связи с разведкой и разработкой минеральных ресурсов, промыслов живых ресурсов, захоронением отходов и других материалов.

Исключительная экономическая зона Российской Федерации регулируется Федеральным законом «Об исключительной экономической зоне» ${ }^{43}$ Настоящий Федеральный

\footnotetext{
${ }^{43}$ См.: СЗ РФ, 1998, N 51, ст. 6273 с изменения и дополнения (в ред. Федеральных законов от 08.08.2001 № 126-ФЗ, от
} 
закон определяет статус исключительной экономической зоны Российской Федерации, суверенные права и юрисдикцию Российской Федерации в ее исключительной экономической зоне и их осуществление в соответствии с Конституцией Российской Федерации, общепризнанными принципами и нормами международного права и международными договорами Российской Федерации. Вопросы, относящиеся к исключительной экономической зоне Российской Федерации и деятельности в ней, не предусмотренные настоящим Федеральным законом, регулируются другими федеральными законами, применимыми к исключительной экономической зоне Российской Федерации и деятельности в ней.

Исключительная экономическая зона Российской Федерации - морской район, находящийся за пределами территориального моря Российской Федерации (далее - территориальное море) и прилегающий к нему, с особым правовым режимом, установленным настоящим Федеральным законом, международными договорами Российской Федерации и нормами международного права.

Определение исключительной экономической зоны применяется также ко всем островам Российской Федерации, за исключением скал, которые не пригодны для поддержания жизни человека или для осуществления самостоятельной хозяйственной деятельности

Внутренней границей исключительной экономической зоны является внешняя граница территориального моря.

Внешняя граница исключительной экономической зоны находится на расстоянии 200 морских миль от исходных линий, от которых отмеряется ширина территориального моря, если иное не предусмотрено международными договорами Российской Федерации (ст.1).

Делимитация исключительной экономической зоны между Российской Федерацией и государствами, побережья которых противолежат побережью Российской Федерации

21.03.2002 № 31-Ф3, от 22.04.2003 № 48-Ф3,от 30.06.2003 № 86-Ф3, от 11.11.2003 № 148-Ф3, от 18.07.2005 № 90-Ф3, от 04.11.2006 № 188-Ф3, от 06.12.2007 № 333-Ф3, от 14.07.2008 № 118-Ф3, от 03.12.2008 № 250-Ф3, от 27.12.2009 № 364-Ф3). или являются смежными с побережьем Российской Федерации, осуществляется в соответствии с международными договорами Российской Федерации или общепризнанными принципами и нормами международного права (ст. 2).

В соответствии с общепризнанными нормами и традициями международного права лицо, совершившее преступление на судне, приписанном к порту Российской Федерации и находящимся в открытом водном или воздушном пространстве вне пределов Российской Федерации, подлежит ответственности по УК РФ, если иное не предусмотрено международным договором Российской Федерации. По УК РФ несёт также ответственность лицо, совершившее преступление на военном корабле или военном воздушном судне Российской Федерации независимо от места их нахождения (ч.3 ст. 11).

В соответствии с договором о принципах деятельности государств по исследованию и использованию космического пространства, включая Луну и другие небесные тела от 27 января 1967 г. ${ }^{44}$ государства - участники Договора (включая и Российскую Федерацию) осуществляют деятельность по исследованию и использованию космического пространства, в том числе Луны и других небесных тел, в соответствии с международным правом, включая Устав Организации Объединенных Наций, в интересах поддержания международного мира и безопасности и развития международного сотрудничества и взаимопонимания.

Государства и в частности Россия, осуществляет свою юрисдикцию над запущенными ими в космическое пространство объектами и их экипажами.

Преступления считаются совершенными на территории Российской Федерации в том случае, когда преступные действия начаты и окончены на её территории, включая и наступление предусмотренного уголовным законом преступного результата, так и в случае, когда преступное действие выполнено

\footnotetext{
${ }^{44}$ См.: Международное публичное право. Сборник документов. Ч.ІІ. М. ТК Вебли, Изд. Проспект, 206 С. 1801.
} 
на территории Российской Федерации, а преступный результат наступил за её пределами.

В завершении можно сказать, что развитие международных отношений в борьбе с международной преступностью, особенно в условиях глобализации, требует тщательного правового регулирования. Правовая регламентация становиться всё более детальной. В результате столь всеобъемлющего договорного регулирования особое значение приобрела проблема соотношения договоров, заключенных в разное время, но касающихся одного и того же вопроса ${ }^{45}$.

Как правило, составы международных преступлений предусмотрены конвенциями, обязывающими участвующие в них государства ввести соответствующие нормы в свое национальное уголовное право, и, соответственно, в случае конвенционных преступлений приговор выноситься на основе национального уголовного права. Эти конвенции содержат также постановления, обязывающие государства в соответствии с международным и национальным правом принимать все практически осуществимые меры с целью предотвращения соответствующих преступлений. В отличии от международных преступлений, список конвенционных преступлений достаточно обширен, поэтому целесообразна их классификация. С известной долей условности в зависимости от своего объекта, т.е. направленности и причинения вреда соответствующим интересам и отношениям, все конвенционные преступления И.И. Лукашук. и А.В. Наумов преступления международного характера подразделяют на пять групп: ${ }^{46}$

К первой группе относят преступления, являющиеся проявлением международного терроризма. В свою же очередь данную группу преступлений они подразделяется на три подгруппы: 1.1. Захват воздушных судов и другие незаконные действия, направленные против безопасности гражданской авиации;

${ }^{45}$ См.: Каламкарян Р.А. Фактор времени в праве договоров. М., 1989. Гл. 3

${ }^{46}$ См.: Лукашук И. И., Наумов А.И. Международное уголовное право. М. Спарк, 1999. С. 132-200.
1.2. Незаконные захват и использование ядерного материала; 1.3. Пиратство и другие незаконные акты, направленные против безопасности морского судоходства.

Ко второй группе относят преступления, посягающие на свободу человека. Рабство и работорговля.

К третьей группе относят преступления, посягающие на общественную экономическую безопасность. Данную группу преступлений подразделяет на шесть подгрупп: 3.1. Экологические преступления; 3.2. Незаконное приобретение и хранение огнестрельного оружия; 3.3. Дорожно-транспортные преступления; 3.4. Хулиганское поведение во время спортивных мероприятий; 3.5. Столкновение морских судов и неоказание помощи на море; 3.6. Разрыв или повреждение подводного кабеля.

К четвертой группе относят преступления, посягающие на здоровье населения и общественную нравственность. Данная группа преступлений подразделяется на три подгруппы: 4.1. Незаконные производство и оборот наркотических средств и психотропных веществ; 4.2. Посягательство на культурные ценности народов; 4.3. распространение порнографии.

К пятой группе они относят преступления экономического характера. К данной группе относить четыре подгруппы преступлений международного характера: 5.1. Подделка денежных знаков; 5.2.Легализация преступных доходов; 5.3. Преступления, совершаемые в исключительной экономической зоне; 5.4.Преступления, совершаемые на континентальном шельфе.

Л.В. Иногамова-Хегай подразделяет преступления международного характера на четыре группы: ${ }^{47}$

К первой группе относит преступления против прав и свобод личности. К этой группе она относит шесть составов преступлений международного характера:

1. рабство и работорговля:

2. похищение и иное насильственное исчезновение людей;

\footnotetext{
${ }^{47}$ См.: Иногамова-Хегай Л.В. Международное уголовное право. СПб.203. С.237-238.
} 
3. торговля и незаконная вербовка людей;

4. нелегальная эмиграция и иммиграция;

5. эксплуатация проституции;

6. пытки и другие жестокие унижающие человеческое достоинство вилы обращения и наказаний.

Ко второй группе относит экономические преступления. К данной группе преступлений она относит три состава преступления:

1. легализация доходов от преступной деятельности (отмывание);

2. фальшивомонетничество (подделка денежных знаков);

3. незаконное использование чужого товарного знака, знака обслуживания и наименования места происхождения товара.

К третьей группе относит коррупционные преступления. К данной группе преступлений она относит три состава преступления:

3.1. получение взятки;

3.2. дача взятки;

3.3. коммерческий подкуп.

К четвертой группе относит преступления против общественной безопасности. Данную группу преступлений она подразделяет на пять подгрупп:

К первой подгруппе относятся преступления против общественной безопасности. К данной подгруппе относит четыре состава:

1. участие в организованной преступной группе;

2. пиратство;

3. незаконный оборот огнестрельного оружия;

4.хулиганство;

Ко второй подгруппе относит транспортные и связанные с транспортом преступления. К данной подгруппе преступлений относит четыре состава преступления:

1. столкновение морских судов;

2. неоказание помощи на море;

3. разрыв и повреждение телеграфного кабеля и трубопроводов;

4. дорожно-транспортные преступления.

К третьей подгруппе преступлений она относит экологические преступления и преступления, совершаемые в исключительной экономической зоне и на континентальном шельфе. К данной подгруппе она относит три состава преступления:
1. экологические преступления;

2. преступления, совершаемые в исключительной экономической зоне;

3. преступления, совершаемые на континентальном шельфе;

К четвертой подгруппе преступлений она относит преступления против здоровья и общественной нравственности. К данной подгруппе она относит два состава преступлений:

1.незаконный оборот наркотических средств и психотропных веществ;

2. распространение порнографии;

К четвертой подгруппе преступлений она относит посягательства на культурное наследие народов. К этой подгруппе она относит два состава преступления:

1. уничтожение или повреждение культурных ценностей народов;

2. невозвращение культурных ценностей.

На основании изложенного мы частично соглашаемся с указанными авторами и в свою же очередь классифицируем преступления международного характера (конвенционные преступления) на пять групп:

Первая группа - преступления, являющиеся проявлением международного терроризма, куда должны войти:

- преступления и некоторые других акты, совершаемые на борту воздушных судов;

- борьба с незаконным захватом воздушных судов;

- международная борьба с захватом заложников;

- преступления против лиц, пользующихся международной защитой, в том числе дипломатических агентов;

- физическая защита ядерного материала ;

- борьба с финансированием терроризма

Вторая групnа - преступления, посягающие на свободу человека, куда должны войти:

- рабство и работорговля;

- похищение и иное насильственное исчезновение людей;

- торговля женщинами и детьми (без цели обращения в рабство);

- пытки и другие жестокие унижающие человеческое достоинств виды обращений и наказаний. 
DOI: $10.7256 / 2226-6305.2014 .1 .11442$

При цитировании этой статьи сноска на dоі обязательна

Международное право и международные организации International Law and International Organizations

Tретья групnа - преступления, посягающие на общественную экономическую безопасность, куда должны войти:

- экологические преступления:

- незаконное приобретение и хранение огнестрельного оружия;

- дорожно-транспортные преступления;

- хулиганское поведение во время спортивных мероприятий;

- столкновение морских судов и неоказание помощи на море;

- разрыв или повреждение подводного кабеля.

Четвертая групnа - преступления, посягающие на здоровья населения и общественную нравственность, куда могут войти:

- незаконные производство и оборот наркотических средств и психотропных веществ;

- посягательство на культурные ценности народов;
- распространение порнографии.

Пята группа - преступления экономического характера, куда могут войти:

- подделка ден ежных 3 наков (фальшивомонетничество);

- легализация преступных доходов;

- преступления, совершаемые в исключительной экономической зоне;

- преступления, совершаемые на континентальном шельфе.

Автор предлагает составы преступлений международного характера (конвенционные преступления) классифицировать на 5 (пять) групп, которые в свою очередь составят особенную часть международного уголовного права. Перечень групп и составы преступлений могут быть расширены, трансформированы и инкорпорированы в национальные уголовные кодексы.

\section{Библиография:}

1. Анцилоттин Д. Курс международного права.Т.1. М.,1961.С.65-67.

2. Броунли Я. Международное право. Т.1. М.,1977.С.65-67.

3. Гавердовский А. С. Имплементация норм международного права. Киев. 1980.С. 62.

4. Действующее международное право.Т1.М.1996 С.356.

5. Капустина М.А. Действие норм международных договоров во времени: теоретико-правовой анализ // Правоведение.1998. № 2.С.51-52.

6. Каламкарян Р.А. Фактор времени в праве договоров. М.,1989. Гл.3

7. Левин Д.А. Актуальные проблемы теории международного права. М., 1974.С.195-196.

8. Левин Д.Б. Проблемы соотношения международного и внутригосударственного права //Сов. государство и право. 1964. № 7. С. 91-92.

9. Лукашук И. И., Наумов А.И. Международное уголовное право. М. Спарк, 1999. С. 132-200.

10. Лукашук И.И. Искусство деловых переговоров. М. , 2001.

11. Лукашук И.И. Современное право международных договоров. В 2 т. Том І. Заключение международных договоров. М. Волтерс Клувер, 2004. С. V.

12. Лукашук И.И. Функционирование международного права. М., 1992. С. 36.

13. Марышева Н.И. Рассмотрение судами гражданских дел с участием ино-странцев. М.1970. С. 96-98.

14. Мюллерсон Р.А. Соотношение международного и национального права. М. 1982. С. 73-75.

15. Международное уголовное право. Учебное пособие/ Под общей ред. В.Н. Кудрявцева. 2-е изд. пераб. и доп. - М.: Наука. 1999. С.38.

16. Международное публичное право. Сборник документов: в 2 ч. ч.I. М. 2006. C.320-339.

17. Современное право международных договоров. Т.ІІ. М.: Волтер Клувер, 2006. С. 89.

18. Талалаев А.Н. Юридическая природа международного договора. М. 1963. С. 251-253.

19. Талалаев А.Н. Венская конвенция о праве международных договоров. Комментарий. М. 1997. С. 116.

20. Терроризм. Правовые аспекты противодействия: нормативные и международные правовые акты с комментариями, научные статьи/под ред. И. Л. Трунова и Ю.С. Горбунова. Изд.и 2-е, перераб. и доп. М. 2007. С. 648-655. 
21. Усенко Е.Т. Соотношение и взаимодействие международного и национального права и Российская Конституция //Московский журнал международного права. 1995. № 2. С. 16

22. Черниченко С.В. Теория международного права. В 2 томах. Том. 1. Современные теоретические проблемы. М., 1999. С. 150-152.

23. Черниченко С.В. Личность и международное право. М., 1974. С. 50-52.

24. Иногамова-Хегай Л.В. Международное уголовное право. СПб. Изд. «юридический центр Пресс» 2003. C.85.

25. Шуршалов В.М. Основания действительности международных договоров. М., 1957. С. 7.

26. Kelsen H. Principler of international Law. N., 1967. P. 177.

27. Landers D. Worterbuch der Deutschen Spraehe. Bd.I. Leipzig, 1848. S.639.

28. Tavernier P. Recherhes sur Papplication dans le temps des actes et de regles en droit international public. P. 1970. P.39-45.

29. Yearbook of the European Convention of Human Rights. 1958-1959. P/ 230-235. Succession of States in relation to General Multilfteral Treaties of wnich the Secretary-general is Depositary (A/CN4/150) P. 73-74, 138.

30. Ю.А. Разумов. Одно из направлений совершенствования законодательства Российской Федерации в сфере пограничной деятельности с учетом национально-правовой имплементации // Национальная безопасность / nota bene. - 2013. - № 1. - C. 104-107. DOI: 10.7256/2073-8560.2013.01.15.

31. Ю.А. Разумов. О некоторых проблемах современного международного права в области военной и пограничной безопасности // Право и политика. - 2013. - № 2. - C. 104-107. DOI: 10.7256/1811-9018.2013.02.9.

32. Ю.А. Разумов. Генезис имплементации норм международного права в военной и пограничной сферах: периоды и факторы // Право и политика. - 2013. - № 1. - C. 104-107. DOI: 10.7256/1811-9018.2013.01.15.

33. Е. Е. Жеребцова. Роль Конституционного Суда Российской Федерации в имплементации решений Европейского Суда по правам человека. // Право и политика. - 2011. - № 1.

34. И.П. Антонов. Теории обеспечения реализации норм международного права в системе национального законодательства ФРГ // Право и политика. - 2009. - № 12.

35. Фардеева И.Н. Роль субъектов Российской Федерации в приграничном сотрудничестве с Европейским Союзом. // NB: Международное право. - 2012. - № 1. - C.26-35. DOI: 10.7256/2306-9899.2012.1.496. URL: http://e-notabene.ru/wl/article_496.html

36. Григорьева О.Г. Участие СССР в создании международных основ правовой помощи по гражданским делам // NB: Международное право. - 2012. - № 1. - C.76-115. DOI: 10.7256/23069899.2012.1.349. URL: http://e-notabene.ru/wl/article_349.html

37. Разумов Ю.А. Некоторые конституционно-правовоые особенности реализации норм международного права в военной сфере в зарубежных странах // NB: Международное право. - 2013. - № 1. - C.171-183. DOI: 10.7256/2306-9899.2013.1.684. URL: http://e-notabene.ru/wl/ article_684.html

38. Сазонова К.Л. «Большая пятерка»и миротворческая деятельность Организации Объединенных Наций: политические и правовые вызовы и угрозы // NB: Международное право. - 2013. - № 2. - C.1-15. DOI: 10.7256/2306-9899.2013.2.4769. URL: http://e-notabene.ru/ wl/article_4769.html

39. Бабин Б.B. Programmatic Regulation in the Modern International Law // NB: Международное право. - 2013.-№ 3.-C.1-35. DOI: 10.7256/2306-9899.2013.3.9302. URL: http://e-notabene.ru/wl/ article_9302.html

40. Каламкарян Р.А. Роль Международного Суда ООН в деле поддержания международного правопорядка // NB: Международное право. - 2013.-№ 1.-C.184-214. DOI: 10.7256/23069899.2013.1.690. URL: http://e-notabene.ru/wl/article_690.htm 


\section{References (transliteration):}

1. Antsilottin D. Kurs mezhdunarodnogo prava.T.1. M.,1961.S.65-67.

2. Brounli Ya. Mezhdunarodnoe pravo. T.1. M.,1977.S.65-67.

3. Gaverdovskii A. S. Implementatsiya norm mezhdunarodnogo prava. Kiev. 1980.S. 62.

4. Kapustina M.A. Deistvie norm mezhdunarodnykh dogovorov vo vremeni: teoretiko-pravovoi analiz // Pravovedenie.1998. № 2.S.51-52.

5. Kalamkaryan R.A. Faktor vremeni v prave dogovorov. M.,1989. G1.3

6. Levin D.A. Aktual'nye problemy teorii mezhdunarodnogo prava. M., 1974.S.195-196.

7. Levin D.B. Problemy sootnosheniya mezhdunarodnogo i vnutrigosudarstvennogo prava //Sov. gosudarstvo i pravo. 1964. № 7. S. 91-92.

8. Lukashuk I. I., Naumov A.I. Mezhdunarodnoe ugolovnoe pravo. M. Spark, 1999. S. 132-200.

9. Lukashuk I.I. Iskusstvo delovykh peregovorov. M. , 2001.

10. Lukashuk I.I. Sovremennoe pravo mezhdunarodnykh dogovorov. V 2 t. Tom I. Zaklyuchenie mezhdunarodnykh dogovorov. M. Volters Kluver, 2004. S. V.

11. Lukashuk I.I. Funktsionirovanie mezhdunarodnogo prava. M., 1992. S. 36.

12. Marysheva N.I. Rassmotrenie sudami grazhdanskikh del s uchastiem ino-strantsev. M.1970. S. 96-98.

13. Myullerson R.A. Sootnoshenie mezhdunarodnogo i natsional'nogo prava. M. 1982. S. 73-75.

14. Talalaev A.N. Yuridicheskaya priroda mezhdunarodnogo dogovora. M. 1963. S. 251-253.

15. Talalaev A.N. Venskaya konventsiya o prave mezhdunarodnykh dogovorov. Kommentarii. M. 1997. S. 116.

16. Terrorizm. Pravovye aspekty protivodeistviya: normativnye i mezhdunarodnye pravovye akty s kommentariyami, nauchnye stat'i/pod red. I. L. Trunova i Yu.S. Gorbunova. Izd.i 2-e, pererab. i dop. M. 2007. S. 648-655.

17. Usenko E.T. Sootnoshenie i vzaimodeistvie mezhdunarodnogo i natsional'nogo prava i Rossiiskaya Konstitutsiya //Moskovskii zhurnal mezhdunarodnogo prava. 1995. № 2. S. 16

18. Chernichenko S.V. Teoriya mezhdunarodnogo prava. V 2 tomakh. Tom. 1. Sovremennye teoreticheskie problemy. M., 1999. S. 150-152.

19. Chernichenko S.V. Lichnost' i mezhdunarodnoe pravo. M., 1974. S. 50-52.

20. Inogamova-Khegai L.V. Mezhdunarodnoe ugolovnoe pravo. SPb. Izd. «yuridicheskii tsentr Press» 2003. S.85.

21. Shurshalov V.M. Osnovaniya deistvitel'nosti mezhdunarodnykh dogovorov. M., 1957. S. 7.

22. Kelsen H. Principler of international Law. N., 1967. P. 177.

23. Landers D. Worterbuch der Deutschen Spraehe. Bd.I. Leipzig, 1848. S.639.

24. Tavernier P. Recherhes sur Papplication dans le temps des actes et de regles en droit international public. P. 1970. P.39-45.

25. Yu.A. Razumov. Odno iz napravlenii sovershenstvovaniya zakonodatel'stva Rossiiskoi Federatsii v sfere pogranichnoi deyatel'nosti s uchetom natsional'no-pravovoi implementatsii // Natsional'naya bezopasnost' / nota bene. - 2013. - № 1. - S. 104-107. DOI: 10.7256/2073-8560.2013.01.15.

26. Yu.A. Razumov. O nekotorykh problemakh sovremennogo mezhdunarodnogo prava v oblasti voennoi i pogranichnoi bezopasnosti // Pravo i politika. - 2013. - № 2. - S. 104-107. DOI: 10.7256/1811-9018.2013.02.9.

27. Yu.A. Razumov. Genezis implementatsii norm mezhdunarodnogo prava v voennoi i pogranichnoi sferakh: periody i faktory // Pravo i politika. - 2013. - № 1. - S. 104-107. DOI: 10.7256/1811-9018.2013.01.15.

28. E. E. Zherebtsova. Rol' Konstitutsionnogo Suda Rossiiskoi Federatsii v implementatsii reshenii Evropeiskogo Suda po pravam cheloveka. // Pravo i politika. - 2011. - № 1.

29. I.P. Antonov. Teorii obespecheniya realizatsii norm mezhdunarodnogo prava v sisteme natsional'nogo zakonodatel'stva FRG // Pravo i politika. - 2009. - № 12. 
30. Fardeeva I.N. Rol' sub"ektov Rossiiskoi Federatsii v prigranichnom sotrudnichestve s Evropeiskim Soyuzom. // NB: Mezhdunarodnoe pravo. - 2012. - № 1. - S.26-35. DOI: 10.7256/2306-9899.2012.1.496. URL: http://e-notabene.ru/wl/article_496.html

31. Grigor'eva O.G. Uchastie SSSR v sozdanii mezhdunarodnykh osnov pravovoi pomoshchi po grazhdanskim delam // NB: Mezhdunarodnoe pravo. - 2012.-№ 1.-S.76-115. DOI: 10.7256/23069899.2012.1.349. URL: http://e-notabene.ru/wl/article_349.html

32. Razumov Yu.A. Nekotorye konstitutsionno-pravovoye osobennosti realizatsii norm mezhdunarodnogo prava v voennoi sfere v zarubezhnykh stranakh // NB: Mezhdunarodnoe pravo. - 2013. - № 1. - S.171183. DOI: 10.7256/2306-9899.2013.1.684. URL: http://e-notabene.ru/wl/article_684.html

33. Sazonova K.L. «Bol'shaya pyaterka» i mirotvorcheskaya deyatel'nost' Organizatsii Ob"edinennykh Natsii: politicheskie i pravovye vyzovy i ugrozy // NB: Mezhdunarodnoe pravo. - 2013. - № 2. - S.115. DOI: 10.7256/2306-9899.2013.2.4769. URL: http://e-notabene.ru/wl/article_4769.html

34. Babin B.V. Programmatic Regulation in the Modern International Law // NB: Mezhdunarodnoe pravo. - 2013. - № 3. - S.1-35. DOI: 10.7256/2306-9899.2013.3.9302. URL: http://e-notabene.ru/wl/ article_9302.html

35. Kalamkaryan R.A. Rol' Mezhdunarodnogo Suda OON v dele podderzhaniya mezhdunarodnogo pravoporyadka // NB: Mezhdunarodnoe pravo. - 2013. - № 1. - S.184-214. DOI: 10.7256/23069899.2013.1.690. URL: http://e-notabene.ru/wl/article_690.htm 